\title{
Health evaluation of three types of baths in patients with severe heart diseases
}

\author{
A valiação econômica de três tipos de banho em pacientes cardiopatas graves \\ Evaluación económica de tres tipos de baño en pacientes con enfermedades cardíacas graves
}

Received: 02/04/2022 | Reviewed: 02/10/2022 | Accept: 02/13/2022 | Published: 02/20/2022

Silvia Regina Martins dos Santos

ORCID: https://orcid.org/0000-0002-9873-7582 Universidade Veiga de Almeida, Brazil E-mail: silviarmsantos2021@gmail.com

Anna Beatriz Alves Pereira Lôbo

ORCID: https://orcid.org/0000-0003-1353-0863 Universidade Federal Fluminense, Brazil E-mail: loboannabeatriz@gmail.com

Fernanda Faria Reis

ORCID: https://orcid.org/0000-0001-7262-1605 Universidade Federal Fluminense, Brazil E-mail: reisf.fernanda@gmail.com

Monyque Evelyn dos Santos Silva ORCID: https://orcid.org/0000-0001-8083-5670 Universidade Veiga de Almeida, Brazil E-mail: monyquevln@gmail.com Aretha Pereira de Oliveira

ORCID: https://orcid.org/0000-0003-1549-7729 Universidade Federal Fluminense, Brazil E-mail: apoliveira.inca@gmail.com

Dalmo Machado

ORCID: https://orcid.org/0000-0003-3587-6224 Universidade Federal Fluminense, Brazil E-mail: dalmomachado.uff@gmail.com

\begin{abstract}
Aim: To analyze the cost of three bed bath technologies in critically ill cardiac patients. Study design: Nonparticipant, prospective, observational, and cost assessment study. Data were collected between February and August 2017, at the cardiac intensive care (ICU) of a university hospital. The convenience sample corresponded to 18 patients in the immediate postoperative period of cardiac surgery. Data were collected within $72 \mathrm{~h}$ after cardiac surgery, with 24-hour washout between baths. Project was approved under the number: 1.823.316. Results: The mean time for bed

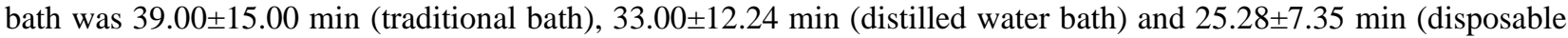
bath). The average final costs identified were R $\$ 45.47$ (US\$ 8.80), R \$ 40.78 (US\$ 7.89) and R\$ 48.36 (US\$ 9.36). Conclusion: The bath with the lowest total average cost was the distilled water bath. The cost category that most burdens the bed baths is human capital, which represents more than $2 / 3$ of the procedures total cost. There are few studies exploring the costs associated to nursing procedures, and this analysis can contribute to discussions about materials purchase and support managers to make better decisions about nursing care.
\end{abstract}

Keywords: Baths; Costs and cost analysis; Nursing care; Cardiovascular surgical procedures; Postoperative care.

\section{Resumo}

Objetivo: Analisar o custo de três tipos de banho no leito em pacientes cardiopatas graves. Métodos: Estudo nãoparticipante, prospectivo, observacional e de avaliação de custos. Os dados foram coletados entre $1^{\circ}$ de fevereiro e 30 de agosto de 2017, na unidade de terapia intensiva cardíaca (UTI) de um hospital universitário. Amostra de conveniência com 18 pacientes em pós-operatório imediato de cirurgia cardíaca. Os dados foram coletados em até 72 horas após a cirurgia cardíaca, com washout de 24 horas entre os banhos. O projeto foi aprovado pelo Comitê de Ética

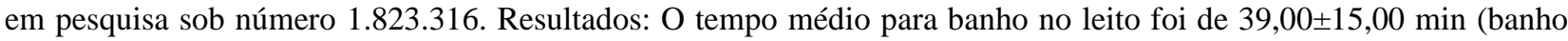

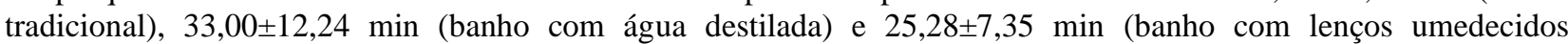
descartáveis). Os custos finais médios identificados foram de $\mathrm{R} \$ 45,47$ (US\$ 8,80), $\mathrm{R} \$ 40,78$ (US\$ 7,89) e $\mathrm{R} \$ 48,36$ (US\$ 9,36), respectivamente. Conclusão: O banho com menor custo médio total foi o banho com água destilada. A categoria de custo que mais onera os banhos no leito é o capital humano, que representa mais de $2 / 3$ do custo total dos procedimentos. Existem poucos estudos explorando os custos associados aos procedimentos de enfermagem, e esta análise pode contribuir para discussões sobre compra de materiais e auxiliar os gestores a tomarem melhores decisões sobre os cuidados de enfermagem. 
Palavras-chave: Banhos; Custos e análise de custo; Cuidados de enfermagem; Procedimentos cirúrgicos cardiovasculares; Cuidados pós-operatórios.

\section{Resumen}

Objetivo: Analizar el costo de tres tecnologías de baño en el lecho en pacientes cardíacos críticamente enfermos. Método: estudio de evaluación de costos, observacional, prospectivo y no participante. Los datos fueron colectados entre el 1 de febrero y el 30 de agosto de 2017, en la unidad de cuidados intensivos cardíacos (UCI) de un hospital universitario. La muestra por conveniencia correspondió a 18 pacientes en el postoperatorio inmediato de cirugía cardiaca. Los datos se recopilaron dentro de las $72 \mathrm{~h}$ posteriores a la cirugía cardíaca, con Washout de 24 horas entre

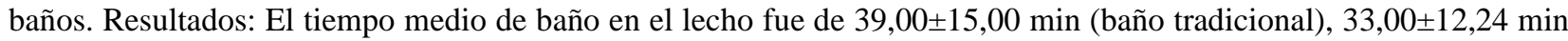
(baño con agua destilada) y 25,28 $\pm 7,35$ min (baño con toallas desechables). Los costos finales medios identificados fueron R \$ 45,47 (US\$ 8,80), R \$ 40,78 (US\$ 7,89) y R \$ 48,36 (US\$ 9,36). Conclusión: El baño con menor costo medio total fue el baño con agua destilada. La categoría de costo que más grava los baños en el lecho es el capital humano, que representa más de $2 / 3$ del costo total de los procedimientos. Existen pocos estudios que exploren los costos asociados a los procedimientos de enfermería, y este análisis puede contribuir a las discusiones sobre la compra de materiales y apoyar a los gerentes para tomar mejores decisiones sobre la atención de enfermería.

Palabras clave: Baños; Costos y análisis de costo; Atención de enfermería; Procedimientos quirúrgicos cardiovasculares; Cuidados posoperatorios.

\section{Introduction}

The economic evaluation area in healthcare joins the economy rationalization to decision making in this sector (Zechmeister-Koss et al., 2019). In Brazil and around the world, health systems and their managers are facing challenges to offer quality health care to the population considering the available resources (Brazil, 2009; Zechmeister-Koss et al., 2019). These challenges can be described as growing technological innovation, proportional arise of spending, restriction of budget resources, industry, media and population impositions and the process of health judicialization (Brazil, 2009; Freitas et al., 2020).

To provide adequate care, managers need trustworthy information about the benefits of a technology and its costs, mainly in the public health system. This information should emerge from clinical evidence to subsidize effectively the decision making and direct formulation of public politics (Laranjeira et al., 2012).

Technologies in health are defined as all interventions which could be used to promote health, including drugs, equipment and technical procedures and organizational systems to offer quality health care (Brazil, 2006; H. P. da Silva et al., 2019). It is fundamental to implement a new research field: Health Technology Assessment (HTA) (Brazil, 2006).

In 1982, World Health Organization (WHO) has highlighted the importance of nurses in debates of health public politics. Nurses constitute the professional with the greatest potential to ensure a rentable assistance related to costs, being frequently represented in all health services, and working closely to final client (Melo et al., 2017).

Despite, historically the economic-financial aspects related to nursing care are undervalued and underexplored (Souza $\&$ Silva, 2017). Few studies treat about scientific evidence to fundament resource acquisition for better nursing care, as well as to know the real costs of nursing work.

This study evaluates the bed bath, an exclusive nursing technique in health institutions and a procedure that, specially in Intensive Care Units (ICU), requires specialized and qualified professionals due to clinical instability of patients (Lima \& Lacerda, 2010; Lôbo et al., 2020). As other nursing techniques, bed bath has presented adaptations and innovations, and no study has been realized to evaluate its real cost.

The aim of this study is to perform an economic evaluation of three bed bath technologies in patients hospitalized in ICU during the cardiac post-operative period. The evaluated technologies were the following: traditional bed bath with water and soap (A); bed bath using a distilled water ampoule bottle (B); bed bath with disposable towers (C). 


\section{Methodology}

Observational, non-participant and prospective study, based on the Brazilian Spreadsheet of Budgetary Impact, which is an electronic spreadsheet to facilitate the grouping of information and automatically makes calculations to estimate the budgetary impact. Following the recommendations of Brazilian Methodological Guideline of Economic Evaluation, this tool was used to guide this study. According to National Ethics in Research Committee, which follows the recommendations of Helsinki Declaration, this Project was approved under the number: 1.823.316.

Data were collected between February and August 2017, in the cardiac ICU of Hospital Universitário, in Rio de Janeiro, Brazil. The cost survey of the materials and inputs needed in each bed Beth and the quantity of items were described. After this survey, the unitary cost of all materials was obtained with Hospital Purchasing Department. The time needed to perform each bed bath was surveyed.

Daily active search was carried out in the ICU and approach to patients who met the eligibility criteria: age from 18 years old, multiparametric monitoring, immediate/mediate postoperative period of cardiac surgery, classified as low risk by the European System for Cardiac Operative Risk Evaluation (EuroSCORE) (Margaryan et al., 2017). Patients with scores other than 15 in the assessment of verbal response on the Glasgow Coma Scale (Nik et al., 2018), pregnant women and patients dependent on mechanical ventilation were excluded. Data collection began the morning after the patients' surgery, with a follow-up period of three consecutive days and the order of bath types randomly defined, using the website http://www.randomization.com. The interval between interventions (washout) was $24 \mathrm{~h}$.

Every day, a researcher recorded the number of professionals and the category of each one in a structured spreadsheet. From the moment the team signaled the beginning of the bath preparation, the investigator began registering the time elapsed from the preparation to the accommodation of the patient. For the timing, each investigator used the smartphone's own stopwatch.

It is important to emphasize that there was no additional training for employees in relation to bathing. These procedures were performed according to the unit's routine and by the team responsible for the patient at the time of data collection.

To conduct the traditional bath (A), it is necessary to use a jar and basin, which, at the end of the bath, need to be washed and disinfected before being stored. In the materials used for bathing patients not colonized by multiresistant microorganisms, 70\% alcohol was used for disinfection. After bathing colonized patients, the solution of choice was $1 \%$ potassium monopersulfate (Virkon®)

For bed bath with distilled water (B), a bottle of 1 liter or two of 500 milliliters of distilled water was used, heated in a microwave oven, exclusively for this purpose, for two minutes on power maximum. After heating, the bottle was perforated at the upper end with a $40 \times 12$ hypodermic needle and used to spray patients before and after being soaped, simulating a spray bath.

For bed bath with disposable wipes (C), one pack of wipes for bathing was used, containing eight units, one for each part of the body (face, right and left upper limbs, anterior and posterior sides of the trunk, right and left lower limbs and perineal region). The wipes have a surfactant solution, with an acid $\mathrm{pH}$, close to the skin $\mathrm{pH}$, and a moisturizing agent enriched with vitamin E (Paulela et al., 2018), which naturally evaporates between 30 and 45 seconds, eliminating the need to rinse and dry the skin with a towel (Larson et al., 2004; Veje et al., 2019).

For analysis of the cost of the human capital of professionals involved in bathing, the base salary of each category was used, according to the Salary Table of Technical-Administrative Servers of Universidade do Estado do Rio de Janeiro. The calculation was performed by dividing the value of the starting base salary of each category by the average number of weeks in 
the month, which is 4.5. Thus, the value of the weekly wage was arrived at, which in turn was divided by 30 , which is the number of hours worked per week. This result was then divided by 60 , which is the number of minutes in an hour, arriving at the result of the salary cost per minute for each category. The formula used to calculate the salary per minute for each category is shown below:

$$
\mathrm{MS}=\frac{(\mathrm{bs} \mid \mathrm{as}) / \mathrm{ww}}{\mathrm{m}}
$$

Hence: MS = minute salary; bs = base salary; as = average of weeks per month $(4.5)$; ww = weekly workload $(30)$; $\mathrm{m}=$ minutes (60).

The cost of electric energy, necessary for operating the microwave oven to heat-distilled water bottles, was not computed, as within the institution's total electric energy cost it becomes immeasurable. The comparison of the time required for each type of bath was performed using a one-way repeated measures analysis of variance (ANOVA) with a level of significance previously fixed at $5 \%$.

\section{Results}

A total of 31 patients who were in the preoperative period voluntarily agreed to participate in the study. Five patients were excluded at the first moment of data collection for several reasons. Twenty-six patients were randomized to the respective bath groups: $\mathrm{ABC}, \mathrm{ACB}, \mathrm{BAC}, \mathrm{BCA}, \mathrm{CAB}$ and $\mathrm{CBA}$. Losses to follow-up included two deaths less than $24 \mathrm{~h}$ after surgery; two deaths with more than $24 \mathrm{~h}$ of surgery and four patients requested to be withdrawn from the research because they considered themselves able to take a spray bath, totaling 18 participating patients (Figure 1). Of the 18 patients who completed the three types of baths proposed, $61.1 \%$ were men with a mean age of $60.72 \pm 11.35$ years. 
Figure 1: Recruitment of immediate postoperative cardiac surgery patients, Pedro Ernesto University Hospital, RJ, Brazil, 2017
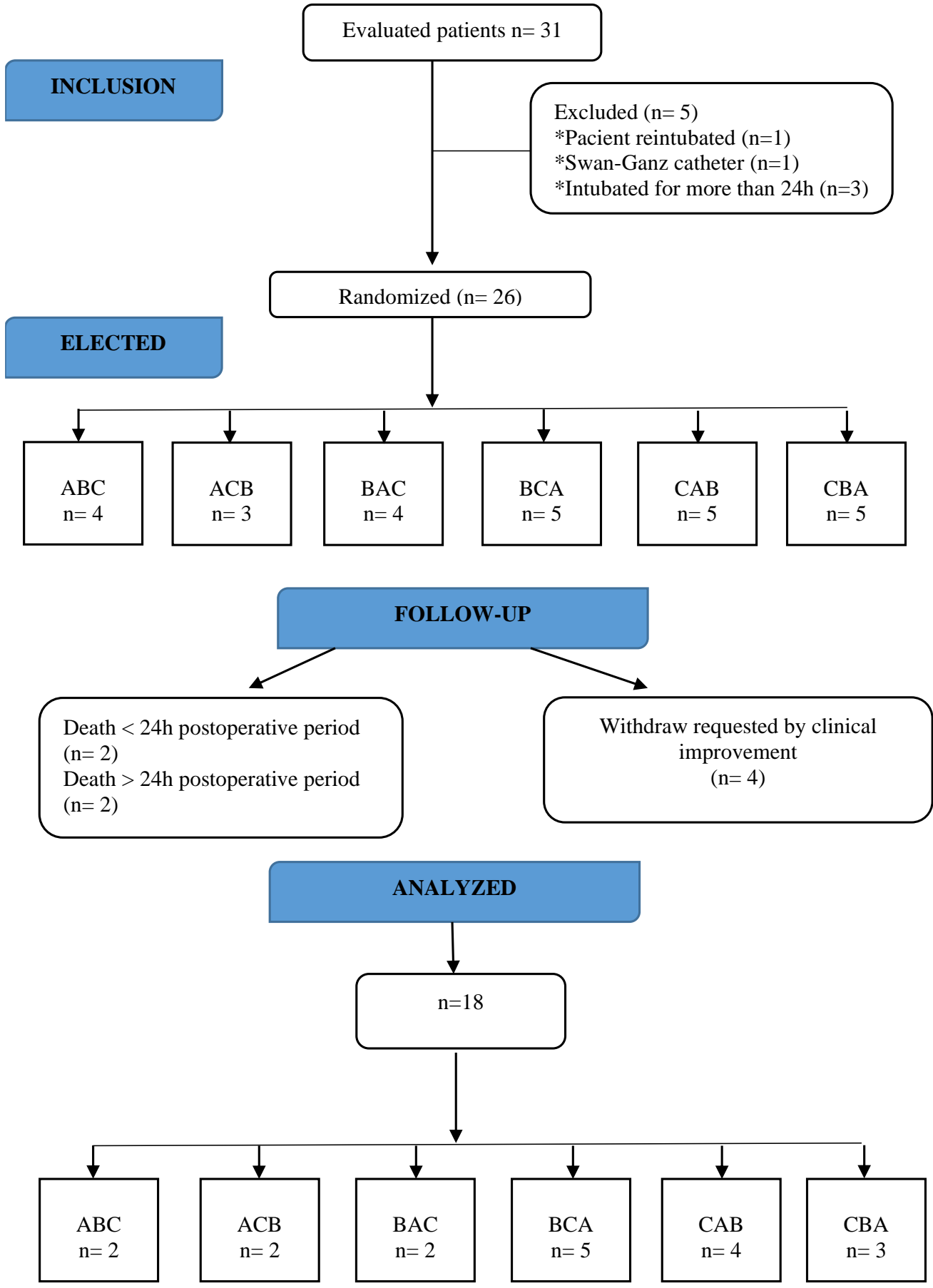

Source: Authors. Adapted from CONSORT guideline.

According to the hospital's purchasing department in August 2017, the personal protective equipment of nursing professionals for bathing represents a cost of $\mathrm{R} \$ 6.42$, consisting of a disposable surgical cap in the amount of $\mathrm{R} \$ 0.09$; a disposable mask for R\$ $0.13 ; 40 \mathrm{~g}$ TNT surgical gowns for R $\$ 5.18$ and six pairs of procedure gloves, at a unit cost of R\$ 0.17 , for a total of $\mathrm{R} \$ 1.02$.

For bed cleaning, $50 \mathrm{ml}$ of $70 \%$ ethyl alcohol at a cost of $\mathrm{R} \$ 0.50$ and 20 units of $7.5 \times 7.5 \mathrm{~cm}$ hydrophilic gauze pads, 
non-sterile, at a unit cost of $\mathrm{R} \$ 0.028$ were used, totaling $\mathrm{R} \$ 0.56$ cents, which, together, represent the cost of $\mathrm{R} \$ 1.06$. Bed cleaning and PPE costs are similar for all baths. The main variations observed were related to the number of professionals and the average time to perform each type of bath. The patient or his family provide the materials for personal use (soap, shampoo, deodorant, toothbrush, toothpaste, mouthwash, comb or hairbrush, moisturizer, and towel). The materials needed to perform the traditional bed bath, as well as the average quantities used and their costs are described in Table 1.

Table 1 - Quantity and cost of materials and supplies used in the traditional bed bath and in the disinfection of materials used in non-colonized patients. Rio de Janeiro, 2017.

\begin{tabular}{|c|c|c|c|c|c|c|c|}
\hline Inputs & Unit & Quant & $\mathrm{R} \$ / \mathrm{un}$ & US\$/un & $\mathrm{R} \$$ & US\$ & Purchase \\
\hline Stainless Steel Bowl of $3,100 \mathrm{ml}$ & un & 01 & 49.95 & 9.67 & Immeasurable & - & Aug/13 \\
\hline Stainless Steel Jar of 2,000 ml & un & 01 & 79.80 & 15.45 & Immeasurable & - & Aug/13 \\
\hline Warm water & 1 & 02 & Immeasurable & - & Immeasurable & - & - \\
\hline Hydrophilic cotton & $\mathrm{g}$ & 200 & 3.98 & 0.77 & 3.98 & 0.77 & Aug/17 \\
\hline $70 \%$ alcohol $*$ & $\mathrm{ml}$ & 100 & 1.00 & 0.19 & 1.00 & 0.19 & Sep/17 \\
\hline $\begin{array}{l}\text { Hydrophilic gauze pad with } 08 \\
\text { folds, non-sterile }\end{array}$ & un & 20 & 0.028 & 0.01 & 0.56 & 0.11 & Sep/17 \\
\hline Total & & - & - & & 5.54 & 1.07 & - \\
\hline
\end{tabular}

1 dollar $=5.16$ reais in 06/02/2021. *70\% alcohol and the swabs listed are used to disinfect the jar and bowl after use. Note: The bowl and jar are considered permanent materials. Source: Purchasing Department of Hospital Universitário

Notably, in patients colonized by infectious agents, the disinfection of the bed is performed using a solution containing 10-ml Virkon (Potassium hydrogenated sulfate, sodium dodecyl benzene sulfonate, potassium monopersulphate, potassium sulfate; Sulfanic acid Excipient qsp 100g), in a total of $\mathrm{R} \$ 0.029 / \mathrm{ml}$, which reduced the cost to $\mathrm{R} \$ 4.83$.

To perform a bath with distilled water, only the absorbent cotton is used to soap the patients, the vial of heated distilled water and a $40 \times 12$ hypodermic needle for perforating the vial. The quantities required and their respective costs are described in Table 2.

Table 2 - Quantity and cost of inputs used in the bed bath with distilled water, Rio de Janeiro, Brazil, 2017

\begin{tabular}{|c|c|c|c|c|c|c|c|}
\hline Inputs & Unit & Quant & $\mathrm{R} \$$ /un & US\$/un & $\mathrm{R} \$$ & US\$ & Purchase \\
\hline Hydrophilic cotton & $\mathrm{g}$ & 200 & 3.98 & 0.77 & 3.98 & 0.77 & Aug/17 \\
\hline Distilled water vial & 1 & 01 & 4.48 & 0.87 & 4.48 & 0.87 & Aug/17 \\
\hline $40 \times 12$ hypodermic needle & $\mathrm{ml}$ & 01 & 0.49 & 0.09 & 0.49 & 0.09 & Aug/17 \\
\hline Total & & - & - & & 8.95 & 1.73 & - \\
\hline
\end{tabular}

Note: The water bottle is heated in the microwave for two minutes at maximum temperature. Source: Purchasing Department of Hospital Universitário 
To perform the bath in the bed with towels for the bath, only a kit of towels for bathing in the disposable bed is needed, commercially available by the brand's representative in Brazil in January/2017 at a cost of R\$18.90 (US\$ 3.66 ). The number and professional category of the team involved in the 54 baths performed were distributed as follows: $59.4 \%$ of the baths were performed by a nurse and a technician; $3.7 \%$ by one nurse and one nursing assistant; $16.6 \%$ by two technicians, $20.3 \%$ by only one technician or nursing assistant.

The mean time to perform the baths was $39 \pm 15$ min for bath $\mathrm{A} ; 33 \pm 12$ min for bath $\mathrm{B}$ and $25 \pm 7$ min for bath $\mathrm{C}$. The mean time of baths in bed $\mathrm{B}$ and $\mathrm{C}$ in patients in the immediate/mediate postoperative period of cardiac surgery was inferior to the mean time of bath A. However, the analysis of variance (ANOVA) revealed that the mean time between bath A is statistically longer compared to that obtained in bath $\mathrm{C}(\mathrm{p}<0.001)$, although it is not significantly different from bath $\mathrm{B}(\mathrm{p}=$ $0.20)$.

In calculating the costs of different bed bath technologies under study, expenditure on supplies and the time required for each type of bath to be performed were included, considering that the nurse does not participate in the preparation of the bath. Table 3 shows the costs of bed baths.

Table 3 - Final cost of the three bed bath technologies with the cost of PPE and bed-cleaning supplies. Rio de Janeiro, Brazil, 2017.

Bath A

Bath B

Bath C

\begin{tabular}{|c|c|c|c|c|c|c|}
\hline \multirow[b]{2}{*}{ Cost/Bath } & \\
\hline & $\mathrm{R} \$$ & US\$ & $\mathrm{R} \$$ & US\$ & $\mathrm{R} \$$ & US\$ \\
\hline Nurse labor cost & 11.86 & 2.30 & 8.85 & 1.71 & 7.38 & 1.43 \\
\hline Technician labor cost & 14.88 & 2.88 & 11.22 & 2.17 & 9.25 & 1.79 \\
\hline Input cost & 5.54 & 1.07 & 8.95 & 1.73 & 18.90 & 3.66 \\
\hline \multicolumn{7}{|l|}{ PPE and material for } \\
\hline bed cleaning costs & 13.19 & 2.55 & 11.76 & 2.28 & 12.83 & 2.48 \\
\hline Total & 45.47 & 8.80 & 40.78 & 7.89 & 48.36 & 9.36 \\
\hline
\end{tabular}

Legend: Bath $\mathrm{A}=$ Traditional bath; Bath $\mathrm{B}=$ Bath with distilled water; Bath $\mathrm{C}=$ Bath with disposable towels. Source: Cardiac ICU at Hospital Universitário Pedro Ernesto.

The cost of the nurse's human capital is $\mathrm{R} \$ 0.59$ and that of the assistant/technician is $\mathrm{R} \$ 0.37$ per minute. The variation in the cost of PPE between the baths was due to the variation in the number of professionals involved in conducting each one.

\section{Discussion}

When analyzing the sociodemographic characteristics of the patients in the study, there was a predominance of male patients and an average age of $60 \pm 11$ years, which was similar to data from the study of the epidemiological profile of the population undergoing myocardial revascularization (Koerich et al., 2017), to the study on anxiety and perception after BL (Lopes et al., 2010) and to the study comparing the traditional bath and bathing with disposable wipes (Larson et al., 2004).

Regarding the nursing staff of the service where the study was conducted, it was observed that it is predominantly composed of women (72\%), with a mean age of 49 years and working at the institution for 18.5 years, results like study that analyzes the profile of the nursing team (M. C. N. Silva \& Machado, 2020). In a study by FIOCRUZ/COFEN, which describes 
the profile of nursing in Brazil, a predominantly female profile is also found (85.1\%), however with an average age of up to 40 years and a greater number of individuals in the professional maturity phase (Machado, 2017).

During the performance of the different types of bath, it was possible to observe that all preparations were performed by the technicians or nursing assistants, as explained above. The nurse, in addition to cleaning the patient, also performed their clinical assessment. It is important to specify the role of nurses in the bed bath, whether in execution or in the supervision, as they are responsible for assessing the patient's skin conditions and for analyzing and managing any instabilities (Möller \& Magalhães, 2015).

At the end of the bath, the nurse participated in making the bed, remained with the patient to perform all the dressings and, finally, made the records and nursing evolution of the assisted patient.

The technicians or nursing assistants are responsible for tidying up the patient unit and for washing, drying, disinfecting all used jars and basins and storing them in an appropriate place. It justifies the higher labor cost of technical professionals and nursing assistants compared to the cost of the nurse's labor.

Of 54 baths performed, $40(74 \%)$ had the participation of two members of the nursing team, which does not exempt the professional from making physical effort, despite being safer for them and for the patient (Costa et al., 2018). In eleven baths $(20.3 \%)$, only one member of the team was responsible for conducting the procedure. When the bath is performed by a single professional, a greater physical effort is evident from the professional, which can lead to musculoskeletal damage or injuries, consequently leading to medical leave. Regarding the patient, this fact increases the possibility of falls, improper immobilization, risk of disconnection or accidental removal of devices, as well as the performance of inadequate body hygiene. In all cases, this can burden the treatment of this patient and the institution (Möller et al., 2015).

The average bath time in bed $\mathrm{B}$ in patients in the immediate postoperative/mediate cardiac surgery condition was $33 \pm 12 \mathrm{~min}$, which is less than the traditional bath time in intensive care patients (Larson et al., 2004).

The bed bath $\mathrm{C}$ had an average time of $25 \pm 7 \mathrm{~min}$, showing a significant difference between this type of bath and the bed bath A. This result is different from what was shown in a study conducted in the United States, in which the comparison between the two types of bath did not show significance $(p=0.08)$ (Larson et al., 2004).

Regarding the long standard deviation in baths A and B, which correspond, respectively, to 38 and $36 \%$ of the average bath time, the time spent preparing the material for the procedure stands out. Notably, in the same US study, the nurses estimate that the preparation time for a traditional bed bath is long, although this variable has not been measured (Larson et al., 2004).

A cluster-randomized clinical trial conducted with 56 elderly people residing in 22 long-term care facilities in the Netherlands found that baths $\mathrm{A}$ and $\mathrm{C}$ proved to be equivalent in terms of preservation of skin integrity $(\mathrm{p}=0.82)$. Regarding costs, the traditional bath presented a total of $€ 5.79$ and the bath with disposable tissues a total of $€ 5.24$ per bath (Schoonhoven et al., 2015).

The time gained by the nursing team with the use of these new bathing technologies can be spent in meeting other needs of the patient in whom the bath was performed or in caring for other patients, such as in the preparation and administration of medications, in the airway aspiration, in the collection of gasometry and laboratory tests, among others, listed in a study that describes the interventions that need 15 min or less (Butcher et al., 2018). Additionally, the time gained in performing a certain activity should be used to promote the planning and systematization processes of nursing care, aiming at a higher quality of patient care (Nøddeskou et al., 2015).

A crossover randomized clinical trial, conducted with 58 bed-restricted patients at a university hospital in Denmark, compared the performance of baths $\mathrm{A}$ and $\mathrm{C}$ and found that the final cost between the two baths was DKK 94.41 and DKK 
115.09 (Nøddeskou et al., 2015), which converted from Danish krone to real (1 Danish krone = 0.84 reais, in 06/02/2021), represent a cost, respectively, of $\mathrm{R} \$ 81.21$ and $\mathrm{R} \$ 99.00$, therefore, a cost higher than those found in our study. The main component of the final cost was related to the payment of professionals who performed the procedure, considering that, in terms of material, the cost of bathing with disposable wipes was 11.84 DDK (R\$ 9.94) and the cost of traditional bathing was of 11.87 DDK (R \$ 9.97). Additionally, in another study conducted in the United States, which also compares the two methods of bed baths in critically ill patients, the final cost between bath A was US\$ 19.87 and bath C of US\$ 18.15 (Larson et al., 2004) which converted to the real represents the respective cost of $R \$ 104.70$ and $R \$ 95.64$. These results reaffirm that the cost of bed baths performed in Brazil is less onerous, especially in relation to the cost of labor for nursing professionals.

When thinking about the lack of nursing human resources in most public hospitals in this country and that the time gained by professionals in performing a bed bath with handkerchiefs can be used for the benefit of differentiated nursing care for the unit's patients, it too can generate resource savings.

Although the absolute values of mean time between baths have a high magnitude, from a statistical viewpoint no significant differences were detected between bath A and bath $B(p=0.0689)$, as well as bath $B$ and bath $C(p=0.1549)$. Thus, the difference was restricted when comparing baths $\mathrm{A}$ and $\mathrm{C}(\mathrm{p}<0.01)$.

It is important to highlight that the Brazilian Spreadsheet of Budgetary Impact is an important tool to support decision-making, although it excludes important items for the actual cost assessment of a procedure in which the cost of human capital and the time required to carry it out must be considered.

This study presents some limitations. It is a single-center study, performed only with stable patients after cardiac surgery. The generalization is associated to patients' profile, and it is not possible to affirm that similar conditions would be found for critical individuals under mechanical ventilation or using vasoactive drugs.

There are few studies exploring the costs associated to nursing procedures, and this analysis can contribute to discussions about materials purchase and support managers to make better decisions about nursing care.

\section{Conclusion}

The identified average final costs of traditional baths, with distilled water and handkerchiefs, were respectively R $\$$ 45.47 (US\$ 8.80), R \$ 40.78 (US\$ 7.89 ) and R 48.36 (US\$ 9.36). The cost category that most burdens the bed baths studied is human capital, which represents more than $2 / 3$ of the total cost of the procedures.

The bed bath with distilled water showed lower final cost and streamlined the bed bath time, providing a lower workload for the nursing staff.

There is no need to apply any statistical tests to compare costs, considering that the differences in absolute values are sufficient to determine which technologies can be incorporated based on the available budget.

\section{References}

Brazil. (2006). Avaliação de Tecnologias em Saúde: institucionalização das ações no Ministério da Saúde. Revista de Saúde Pública, 40(4), 743-747. https://doi.org/10.1590/s0034-89102006000500029

Brazil. (2009). Avaliação de Tecnologias em Saúde: Ferramentas para a Gestão do SUS. In Ministério da Saúde. http://bvsms.saude.gov.br/bvs/publicacoes/avaliacao_tecnologias_saude_ferramentas_gestao.pdf

Butcher, H. K., Bulechek, G. M., Dochterman, J. M., \& Wagner, C. M. (2018). Nursing interventions classification (NIC) seventh edition. Elsevier, 8 Pt 2, 1368. https://doi.org/10.1097/00006216-199317030-00016

Costa, G. S., Souza, C. C., Diaz, F. B. B. de S., \& Toledo, L. V. (2018). Bed bath in critical care patients: An integrative review. Revista Baiana de Enfermagem, 32, 1-14. https://doi.org/10.18471/rbe.v32.20483 
Freitas, B. C., Fonseca, E. P., \& Queluz, D. de P. (2020). A Judicialização da saúde nos sistemas público e privado de saúde: uma revisão sistemática. Interface: Communicação, Saúde, Educação, 24(e190345), 1-17. https://doi.org/10.1590/Interface.190345

Koerich, C., Marcellino, G., Lanzoni, D. M., Hörner, B., Meirelles, S., Baggio, A., Dorneles, G., Higashi, C., \& Erdmann, A. L. (2017). Epidemiological profile of the population who underwent myocardial revascularization and access to the unified health system.

Laranjeira, F. de O., \& Petramale, C. A. (2012). A avaliação econômica em saúde na tomada de decisão: a experiência da CONITEC. BIS, Bol. Inst. Saúde (Impr.), 14(2), 165-170. http://periodicos.ses.sp.bvs.br/pdf/bis/v14n2/v14n2a06.pdf

Larson, B. E. L., Ciliberti, T., Chantler, C., Abraham, J., Lazaro, E. M., Venturanza, M., \& Pancholi, P. (2004). Comparison of traditional and disposable bed baths in critically ill patients. American Journal of Critical Care, 13(3), 235-242.

Lima, D. V. M., \& Lacerda, R. A. (2010). Hemodynamic oxygenation effects during the bathing of hospitalized adult patients critically ill: Systematic review. ACTA Paulista de Enfermagem, 23(2), 278-285. https://doi.org/10.1590/S0103-21002010000200020

Lôbo, A. B. A. P., Santos, S. R. M. dos, Mesquita Júnior, L. C. de, Fernandes, R. M., Santos, M. P., Reis, F. F., Silva, M. É. dos S., Oliveira, A. P. de, \& Lima, D. V. M. de. (2020). Efetividade oxi-hemodinâmica de três tipos de banho no leito de pacientes cardiopatas graves: crossover Oxyhemodynamic. Research, Society and Development, 9(8), e954986249. https://doi.org/10.1017/CBO9781107415324.004

Lopes, J. de L., Nogueira-Martins, L. A., Gonçalves, M. A. B., \& Barros, A. L. B. L. de. (2010). Comparing Levels of Anxiety During Bed and Shower Baths in Patients with Acute Myocardial Infarction. Revista Latino-Americana de Enfermagem, 18(2), 217-223. https://doi.org/10.1590/s0104-11692010000200012

Machado, M. H. (2017). Perfil da enfermagem no Brasil: relatório final.

Margaryan, R., Moscarelli, M., Gasbarri, T., Bianchi, G., Kallushi, E., Cerillo, A. G., Farneti, P., \& Solinas, M. (2017). EuroSCORE Performance in Minimally Invasive Cardiac Surgery. Innovations: Technology and Techniques in Cardiothoracic and Vascular Surgery, 12(4), 282-286. https://doi.org/10.1097/IMI.0000000000000377

Melo, T. de O., \& Lima, A. F. C. (2017). Cost of nursing most frequent procedures performed on severely burned patients. Revista Brasileira de Enfermagem, 70(3), 481-488. https://doi.org/10.1590/0034-7167-2015-0034

Möller, G., \& Magalhães, A. M. M. de. (2015). Bed Baths: Nursing Staff Workload and Patient Safety. Texto \& Contexto - Enfermagem, 24(4), 1044-1052. https://doi.org/10.1590/0104-0707201500003110014

Nik, A., Sheikh, M., Reza, M., Zarifian, A., Ghayoor, E., \& Bahadoorkhan, G. (2018). The Efficacy of Glasgow Coma Scale (GCS) Score and Acute Physiology and Chronic Health Evaluation (APACHE) II for Predicting Hospital Mortality of ICU Patients with Acute Traumatic Brain Injury. Bulletin of Emergency and Trauma, 6(2), 141-145. https://doi.org/10.29252/beat-060208.Please

Nøddeskou, L. H., Hemmingsen, L. E., \& Hørdam, B. (2015). Elderly patients' and nurses' assessment of traditional bed bath compared to prepacked single units - randomised controlled trial. Scandinavian Journal of Caring Sciences, 29(2), 347-352. https://doi.org/10.1111/scs.12170

Paulela, D. C., Bocchi, S. C. M., Mondelli, A., Martin, L. C., \& Sobrinho, A. R. (2018). Effectiveness of bag bath on microbial load: clinical trial. ACTA Paulista de Enfermagem, 31(1), 7-16.

Schoonhoven, L., van Gaal, B. G. I., Teerenstra, S., Adang, E., van der Vleuten, C., \& van Achterberg, T. (2015). Cost-consequence analysis of "washing without water" for nursing home residents: A cluster randomized trial. International Journal of Nursing Studies, 52(1), 112-120. https://doi.org/10.1016/j.ijnurstu.2014.08.001

Silva, H. P. da, \& Elias, F. T. S. (2019). Incorporação de tecnologias nos sistemas de saúde do Canadá e do Brasil: perspectivas para avanços nos processos de avaliação. Cadernos de Saude Publica, 35(suppl 2), e00071518. https://doi.org/10.1590/0102-311X00071518

Silva, M. C. N., \& Machado, M. H. (2020). Health and work system: Challenges for the nursing in Brazil. Ciencia e Saude Coletiva, 25(1), 7-13. https://doi.org/10.1590/1413-81232020251.27572019

Souza, S. E. S. M. de, \& Silva, A. R. da. (2017). Contribuição do enfermeiro no processo de gerenciamento de custo nas instituições hospitalares. Revista Eletrônica Gestão \& Saúde, 08(02), 338-362. https://periodicos.unb.br/index.php/rgs/article/view/3732/3408

Veje, P. L., Chen, M., Jensen, C. S., Sørensen, J., \& Primdahl, J. (2019). Bed bath with soap and water or disposable wet wipes: Patients' experiences and preferences. Journal of Clinical Nursing, 28(11-12), 2235-2244. https://doi.org/10.1111/jocn.14825

Zechmeister-Koss, I., Stanak, M., \& Wolf, S. (2019). The status of health economic evaluation within decision making in Austria. Wiener Medizinische Wochenschrift, 169(11-12), 271-283. https://doi.org/10.1007/s10354-019-0689-8 